\title{
Warisan Kolonisasi Inggris di Kenya: Kekerasan Struktural terhadap Etnis Kenya-Somali di Kenya
}

\author{
Greaty Fitraharani dan Arfin Sudirman \\ Universitas Padjajaran
}

\begin{abstract}
Abstrak
Penelitian ini dilatarbelakangi oleh warisan kolonisasi Inggris di perbatasan antara Kenya dan Somalia yang mengakibatkan keberadaan kelompok etnis Somali di North Eastern Province. Aktor yang terlibat adalah Pemerintah Kolonial, Pemerintah Kenya dan Etnis Kenya-Somali. Fokus dari penelitian ini adalah menjelaskan kekerasan struktural terhadap kelompok Etnis Kenya-Somali pasca kolonisasi di Kenya. Peneliti menggunakan structural violence dari Johan Galtung dan pendekatan Post-Colonialism dari Frantz Fanon untuk dapat menerapkan teori tersebut ke dalam fenomena kekerasan struktural yang terjadi pada etnis Kenya-Somali. Tujuan dari penelitian ini adalah untuk menerapkan pendekatan structural violence sebagai pisau analisis pengidentifikasian permasalahan kesenjangan sistem yang kerap terjadi di negara dunia ketiga akibat warisan sistem kolonisasi.
\end{abstract}

Kata Kunci: Kekerasan Struktural, KelompokMinoritas, Post-Colonialism, Kenya-Somali, North Eastern Province

The background of this research is based by the legacy of British colonization on the border between Kenya and Somalia that led to the existence of Somali ethnic groups in the North Eastern Province. Actors involved are the Colonial Government, the Government of Kenya and the Kenya-Somali Ethnic. The focus of this study is to explain the structural violence against ethnic groups of Kenya-Somali in the post-colonization era in Kenya. Researchers used Johan Galtung's structural violence concept and postcolonial approach by Frantz Fanon to apply the theory to the phenomenon of structural violence that occurred in the ethnic of Kenya-Somali. The purpose of this study is to implement structural violence approach as a tool of analysis in identifying systemic problems that often occurs in third world countries as the legacy of colonization system.

Key Words: Structural violence, Minorities, Post-colonialism, KenyaSomali, North Eastern Province 
Kolonialisme merupakan bagian dari sejarah kelam di benua Afrika. Dampak dari periode tersebut pun masih mengakar hingga kini dan menimbulkan berbagai permasalahan baru, salah satunya adalah pembagian batas teritori berdasar kepemilikan wilayah kekuasaan bangsa Eropa (Partition of Africa). Pembagian batas teritori yang tidak berdasar pada etnisitas mengakibatkan satu kelompok etnis dapat terpecah ke dalam dua wilayah negara yang berbeda (Michalpoulos, 2012). Saat Perang Dunia I, Inggris membagi sebagian wilayah timur Jubaland yang secara ekslusif dihuni oleh etnis Somali di selatan Somalia kepada Italia karena telah bergabung dengan pihak sekutu, sedangkan bagian barat Jubaland tergabung dalam teritori British East Africa dengan nama Northern Frontier District (Low \& Smith, 1976). Akibatnya, pasca kemerdekaan Kenya, etnis Somali mendiami bagian timur laut Kenya dan memegang 6\% dari total populasi Kenya (Patinkin, 2014).

Pasca kemerdekaan Kenya, muncul berbagai kekerasan baik secara langsung maupun tidak langsung terhadap kelompok etnis Somali. Baik itu konflik yang berakibat perang, Shifta War (1963-1968), maupun narasi 'permusuhan' yang diarahkan kepada kelompok Somali (Otunnu, 1992). Narasi tersebut mengakibatkan kesenjangan sistem yang sangat terasa, baik dalam pembangunan ekonomi yang tidak merata maupun distribusi kebutuhan dasar yang tidak seimbang. Kesenjangan tersebut merupakan akibat dari warisan sistem pada masa kolonial terhadap etnis Somali.

\section{Post Colonialism dan Structural Violence}

Post-Colonialism dapat menjelaskan kondisi sistem yang pernah dipengaruhi oleh sejarah kolonisasi. Pemikiran Fanon atas dekolonisasi sebagai bagian dari aksi kekerasan karena mengakibatkan kekacauan dalam sistem yang ingin dibangun oleh pemerintah di negara yang baru merdeka yakni Kenya. Frantz Fanon dalam bukunya, Black Skin White Mask (1986) memaparkan bahwa di masa kolonial terdapat sebuah keadaan yang menimbulkan inferioritas diri yang dirasakan oleh penduduk yang terjajah akibat perbedaan perlakuan maupun cara pandang para penjajah kepada yang terjajah. Sebagai pihak yang merasa inferior, keinginan untuk meniru, membuktikan bahkan menjadi bagian dari seorang kulit putih sudah tertanam dalam benak para pribumi. "For the black man 
there is only one destiny. And it is white" (1986: 12). Fanon menyadari bahwa kulit hitam merupakan bagian dari objek masyarakat kulit putih, 'spesies' lain yang berbeda dengan mereka.

Dalam buku lainnya, The Wretched of the Earth (1963) Fanon menjelaskan proses dekolonisasi seharusnya menjadi momentum bagi bangsa yang terjajah untuk dapat mendefinisikan kembali bangsanya. Dekolonisasi pada prosesnya hanya membuat sebuah tatanan baru dalam 'negara baru' yang diikuti dengan tatanan hubungan diplomatik, ekonomi dan tren politik namun tidak benarbenar terlahir sebagai tabula rasa dalam karakter dan pemikirannya sendiri. Menurut Fanon, permulaan dekolonisasi harus dimulai dengan sistem bottom-up, bawah ke atas (1963: 35) yang kemudian dirumuskan menjadi sebuah sistem yang dapat memecahkan permasalahan sesungguhnya dari dan untuk masyarakat kembali.

Hingga menimbulkan kerugian di pihaketnis Somali dalam kerangka sistem, lebih lanjut konsep structural violence dari Johan Galtung akan dipaparkan untuk menjelaskannya. Kekerasan struktural dibangun dalam sebuah kesenjangan sistem yang menghasilkan distribusi power yang hanya memenangkan satu pihak dan mengancam keberlangsungan atas kesempatan hidup pihak lainnya. Contoh nyata dari bentuk kekerasan struktural menurut Galtung yakni sumberdaya dan pendidikan tidak terdistribusi secara merata, kesenjangan pendapatan terjadi di daerah tertentu, pelayanan kesehatan tidak dirasakan oleh semua kelompok. Galtung membagi empat bentuk ancaman terhadap kebutuhan dasar manusia yakni kebutuhan untuk kelangsungan hidup, kesejahteraan, identitas, dan kebebasan (Galtung, 1990: 292).

Tabel 1. Bentuk Ancaman Kekerasan Langsung dan Struktural

\begin{tabular}{|c|c|c|c|c|}
\hline $\begin{array}{c}\text { Violence } \\
\text { Typology }\end{array}$ & \multicolumn{4}{|c|}{ Need Groups } \\
\hline \multirow{4}{*}{$\begin{array}{c}\text { Structural } \\
\text { Violence }\end{array}$} & $\begin{array}{c}\text { Survival } \\
\text { Needs }\end{array}$ & $\begin{array}{c}\text { Well-being } \\
\text { Needs }\end{array}$ & $\begin{array}{c}\text { Identity } \\
\text { Needs }\end{array}$ & Freedom Needs \\
\cline { 2 - 5 } & Exploitation & Exploitation & Penetration & Marginalization \\
& $A$ & B & Segmentation & Fragmentation \\
\hline
\end{tabular}


Kelangsungan hidup yang dimaksud oleh Galtung adalah kebebasan dari kekerasan atau keamanan (safety) (Galtung, 1978). Pada ancaman terhadap kesejahteraan, hasil akhirnya bisa berupa kematian seperti pembiaran yang dilakukan topdogs (pihak berkuasa) terhadap underdogs (pihak yang tidak berdaya) dalam satu kondisi menyedihkan yang tidak diinginkan, 'unwanted state of misery'. Kondisi tersebut seperti hal nya kemiskinan yang permanen dan menyebabkan gizi buruk dan penyakit pada underdogs. Kekerasan strukturaljuga dapatmempengaruhi pikirandansemangatunderdogs. Bentuknya dapat melalui penetrasi atau proses penanaman nilainilai secara paksa dari topdogs terhadap underdogs di mana nilainilai tersebut tidak lagi dipertanyakan namun mulai diterima oleh underdogs padahal kondisi tersebut menguntungkan pihak topdogs. Atau, segmentasi dimana topdogs hanya memperlihatkan sebagian dari apa yang sebenarnya terjadi kepada underdogs (Galtung, 1990: 294). Bentuk eksploitasi dalam bentuk kebebasan dapat melalui marginalisasi yakni proses dimana underdogs dibatasi dan dipinggirkan dalam berbagai akses maupun urusan oleh topdogs (Galtung, 1990: 294). Keempat, proses fragmentasi dimana topdogs memecah belah kelompok underdogs untuk melemahkan power yang dimiliki kelompok tersebut (Galtung, 1990: 294).

\section{Kekerasan Struktural terhadap Kelompok Etnis Kenya-Somali}

Ide utama dari kekerasan struktural adalah tidak adanya aktor atau subjek yang bisa disalahkan secara langsung atas keterlibatannya dalam sebuah kesenjangan sistem yang menghasilkan distribusi power yang hanya memenangkan satu pihak dan mengancam keberlangsungan atas kesempatan hidup (life chances) pihak lainnya. Tidak adanya aktor yang dapat disalahkan ini karena struktur yang bermain di dalam kesenjangan tersebut dan tidak mengatasnamakan suatu aktor secara langsung. Namun terdapat indikasi siapa yang berkuasa dan dapat memengaruhi strukturlah yang menggunakan kekuasaannya untuk secara sengaja atau tidak membiarkan kesenjangan terjadi terhadap pihak lain.

Untuk sampai ke wacana 'musuh' dan kelompok etnis yang 'bermasalah', perlu adanya konsistensi narasi yang dialamatkan kepada etnis Kenya-Somalis. Galtung dalam artikelnya "Cultural Violence" menyatakan kekerasan struktural ini mengancam empat 
kebutuhan dasar yakni survival needs, well-being needs, identity needs, dan freedom needs. Ide utama dari berbagai bentuk ancaman kekerasan struktural terhadap kebutuhan dasar ini ini adalah eksplotasi, "The archetypal violent structure, in my view, has explotation as a center-piece" (Galtung, 1990). Sistem yang eksploitatif mengakibatkan pertukaran interaksi yag tidak seimbang dan hal tersebut menjadi sebuah struktur dalam ukuran kebutuhan dasar.

\section{Ancaman terhadap Kebutuhan Kelangsungan Hidup (Survival Needs)}

Sistem yang tidak dapat melakukan proteksi keamanan terhadap virus yang menular sehingga terhadap masyarakatnya mengakibatkan kematian perlahan. Secara konkrit berbagai struktur dan sistem yang gagal melindungi masyarkat etnis Somali dari rasa aman. Data dari International Center for Transitional Justice (Robins, 2011) menekankan pada marginalisasi sistem dan diskriminasi dari berbagai layanan publik yang tidak terdapat di dapat di North Eastern. Kartu identitas merupakan isu paling krusial yang banyak diangkat oleh berbagai laporan dari pelanggaran HAM. "The first point that northeasterners make is challange they face in gaining access to an identity card, the very symbol of Kenyan citizenship, that in some communities almost no possessed" (Robins, 2011). Kenya National Commission on Human Rights (2007) sebagai badan pemerintah yang ditunjuk khusus untuk mengevaluasi pelanggaran HAM yang pernah dilakukan Pemerintah pun mengakui banyak keluhan terhadap sulitnya mendapatkan kartu identitas.

Hal ini menjadi permasalahan karena dengan tidak memiliki kartu identitas tersebut mereka tidak akan dapat merasakan berbagai hakhak dasar sebagai warga negara. Hak-hak dasar tersebut seperti hak berpolitik dalam menyampaikan suaranya di pemilihan umum, sulitnya membeli properti dan mengakses pendidikan yang lebih tinggi untuk dapat mengejar pekerjaan yang lebih baik. Paling buruknya, kelompok etnis Kenya-Somali sangat rentan mendapat kekerasan seperti penangkapan secara paksa oleh angkatan bersenjata karena dikira imigran ilegal yang tidak memiliki kelengkapan dokumen kartu identitas (Kenya National Commission on Human Rights, 2007). 
Pada masa pemerintahan Jomo Kenyatta (1963-1978), Shifta War merupakan peristiwa yang paling membekas antara Pemerintah Kenya dan komunitas Somali. Pasukan milier bertanggung jawab atas pembunuhan massal, penyiksaan, kekerasan seksual dan pemerkosaan terhadap warga sipil pada waktu itu. Diperkirakan korban antara 2.000 - 7.000 orang. Sedangkan korban yang ditimbulkan dari pihak Somali lebih sedikit dari korban yang ditimbulkan dari pasukan militer Kenya. Pasukan militer Kenya juga bertanggung jawab atas penyitaan dan pembunuh hewan ternak dengan meracuni sumber air yang mengakibatkan korban bagi hewan ternak maupun warga sipil. Jumlah kerugian $70 \%-$ 90\% hewan ternak (Kenya Transitional Justice Network, 2013). Hal ini mengindikasikan tidak berhasilnya pemerintah melindungi salah satu kelompok masyarakatnya dari rasa tidak aman.

\section{Ancaman terhadap Kebutuhan Kebutuhan akan Kesejahteraan (Well-being Needs)}

Ancaman tersebut seperti kemiskinan yang permanen dan menyebabkan gizi buruk atau penyakit pada underdogs dan akses terhadap pendidikan. Contoh konkrit yang terjadi pada etnis Somali adalah permasalahan kemiskinan mutlak, akses pendidikan yang sangat kurang dan memprihatinkan, akses air dan sanitasi yang masih perlu banyak dibantu. Permasalahan Kemiskinan, menurut data dari Save The Children (2007) di North Eastern Province (NEP) di mana etnis Kenya-Somali maryoritas bermukim, kemiskinan bersifat absolut hingga mencapai $49 \%$ apabila dibandingkan dalam skala nasional dan $74 \%$ pada skala provinsi. NEP ini dinobatkan sebagai provinsi termiskin di Kenya. Dalam ukuran kemampuan literatur pun NEP memiliki standar terendah di mana umur 15 tahun keatas dibandingkan dengan skala membaca nasional $79 \%$, di NEP hanya $28 \%$ saja. Di Mandera sendiri hanya $6 \%$ dari total wanita yang bisa membaca. Untuk data anak yang sudah diimunisasi, yang berumur 12-23 bulan pun walaupun per data nasional ada $66 \%$ yang sudah mendapat imunisasi namun di NEP hanya mencapai $21 \%$ dan $8 \%$ sendiri untuk Mandera (Save the Children, 2007).

Permasalahan Pendidikan. North Eastern Province berada pada tingkat terendah dalam pengaksesan pendidikan apabila 
dibandingkan dengan total akses nasional, baik itu sekolah pra-dasar 24.383/2.247.071, sekolah dasar 414.541/9.425.390, pendidikan sekunder 60.133/1.796.467 dan akses untuk pendidikan universitas hanya 2.431/198.119. Kesenjangan yang terlalu kentara pada akses pendidikan merupakan salah satu contoh nyata kekerasan struktural di wilayah NEP. Pendidikan menjadi salah satu faktor yang krusial karena dapat memberikan perbaikan terhadap keadaan pihak underdogs, namun apabila dihambat pendistribusiannya akan sangat memberikan kerugian beruntun terhadap kesempatan hidup pihak underdogs.

Untuk akses pendidikan terhadap wanita juga sangat rendah, apalagi dalam permasalahan pendidikan seputar kesehatan ibu, imunisasi anak, dan penggunaan alat kontrasepsi. Menurut Economic Survey, penggunaan alat kontrasepsi yang berarti mengindikasikan pengetahuan mengenai alat tersebut juga adalah di wilayah Central dan Eastern Region, masing-masing 73\% dan $70 \%$, sedangkan di wilayah North Eastern Region hanya sebesar 3\% (Kenya National Bureau of Statistics, 2015). Minimnya penggunaan alat kontrasepsi dapat berkontribusi baik apabila populasi di suatu wilayah sangat rendah, selain itu alat kontrasepsi juga dibutuhkan apabila satu keluarga memiliki kemampuan ekonomi yang rendah sehingga perlu adanya kontrol terhadap kepemilikan anak.

Penulis juga merujuk pada data dari Pemerintah Kenya saat melakukan sensus tahun 2009 yang dipublikasikan pada 2010 oleh Minister of State for Planning, National Development and Vision 2030 untuk data pendidikan yang mana North Eastern pada masing-masing tingkat pendidikan hanya berjumlah (preprimary) 24.383, (primary) 414.541, (secondary) 60.133, (university) 2.431 orang. Kesehatan merupakan kebutuhan dasar dari setiap manusia karena berpengaruh langsung pada tingkat kematian dan kelahiran dalam suatu negara. Dalam akses kesehatan, khususnya keamanan dalam proses melahirkan di North Eastern Province, data menunjukkan $81 \%$ masih melakukan proses tersebut di rumah, dengan penggunaan fasilitas kesehatan hanya sebesar $17 \%$. Alasan dari pengaksesan akses kesehatan yang minim dikarenakan aksesnya tidak buka (22\%), terlalu jauh atau tidak memiliki transport (46\%) dan tidak memerlukan (18\%) (Muuring, 2011). Selain akses terhadap bangunan kesehatan, tenaga ahli juga tidak mumpuni seperti bidan dan dokter anak dan mengakibatkan 
seringnya masyarakat di NEP menggunakan jasa dukun anak atau Traditional Birth Attandance (TBA) dan menjadi yang tertinggi di Kenya (64\%).

Apabila dilihat pada penggunaan akses air sebagai sumber kehidupan manusia di NEP secara alami seperti kolam, bendungan dan danau aksesnya cukup besar yakni 16,3\%, air hujan 2,5\% , untuk mata air seperti sumur atau lubang-bor air pun besar hingga $51,1 \%$. Namun untuk pengembangan infrastruktur air seperti pipa dan saluran air berada di masing-masing $11,6 \%$ dan $5,1 \%$. Dalam pengaksesan terhadap salah satu kebutuhan hidup yakni air, masyarakat NEP cenderung mengandalkan air yang berasal langsung dari alam daripada mengaksesnya menggunakan alat atau infrastruktur lainnya. Walaupun begitu, wilayah NEP memiliki keadaan geografis yang kering seperti di gurun sehingga sangat mungkin bagi mereka untuk merasakan kekeringan di kala alam tidak bisa diandalkan.

Sedangkan untuk data sanitasi berdasar pada Human Waste Disposal di masing-masing provinsi. Berdasarkan data di atas, akses sanitasi ini juga berarti infrastruktur terhadap alat-alat pembuangan. Untuk masing-masing akses terhadap alat pembuangan sebagian besar berada di urutan paling bawah dari setiap provinsi seperti selokan air kotor, septic tank, cess pool, jamban. Namun, akses menggunakan semak-semak merupakan alat pembuangan yang paling tinggi digunakan oleh mayoritas etnis Kenya-Somali di North Eastern Province dengan $63 \%$ dari populasi. Ini berarti untuk akses sanitasi di NEP masih di bawah standar kebersihan, apalagi dalam pengadaan peralatan untuk sistem kebersihan di sana.

Kesejahteraan memegang peranan kunci berkembang atau tidaknya seseorang, apabila secara ekonomi berada pada ambang kemiskinan untuk mengembangkan diri dan potensinya di pendidikan dan kesehata pun sulit. Oleh sebab itu perlu struktur yang benar-benar membangun kesejahteraan masyarakatnya. "All of this happens within complex structure and at the end of long, higly ramified causal chains and cycles" (Galtung, 1990: 294). Kompleksitas struktur sosial yang sulit untuk diubah menjadikan peneliti melihat Kenya sebagai salah satu contoh di mana ketidakseimbangan terjadi dalam kesempatan hidup antara wilayah North Eastern Province dengan wilayah lainnya di Kenya. Memang benar terdapat latar belakang historis yang 
membuat perbedaan perlakuan sejak zaman kolonisasi terhadap etnis Somali di NEP, namun hal tersebut tidak dapat mempengaruhi kesempatan untuk hidup yang seharusnya dimiliki oleh masingmasing individu di dalam sebuah negara. Pemerintah Kenya membuat sistem yang berujung pada kompleksitas bercabang yang sudah terjadi sejak bertahun-tahun lamanya sehingga sulit sekali untuk mengubah kondisi kesejahteraan terhadap pihak kelompok minoritas seperti underdogs yakni Kenya-Somali.

\section{Ancaman terhadap Kebutuhan akan Identitas (Identity Needs)}

Pada aspek identity needs, kekerasan struktural dapat dilakukan melalui penetrasi dan segmentasi. Untuk implementasi yang ada di kasus etnis Kenya-Somali hanya terbatas pada penetrasi. Dalam pengertiannya, penetrasi merupakan upaya penanaman nilai-nilai oleh topdogs kepada underdogs agar underdogs dapat memaklumi berbagai perlakuan yang dilakukan topdogs, segmentasi menjadikan underdogs hanya dapat melihat sebagian dari apa yang sebenarnya dilakukan topdogs terhadap mereka. Segmentasi tidak dapat diaplikasikan ke Kenya-Somali karena terdapat kesadaran penuh dari pihak Kenya-Somali terhadap nilai-nilai identitas yang mereka miliki hingga ingin menyatukan diri mereka dengan Somalia atas dasar kesamaan identitas.

Dua cara yang dapat diaplikasikan oleh kekerasan struktural adalah penetrasi atau penanaman nilai-nilai, ini bermula dari kolonisasi di wilayah NEP yang masih menjadi NFD. Sejarah fragmentasi sebagian masyarakat Somalia yang harus menerima wilayahnya dikuasai oleh Inggris dan kemudian diberikan kepada Kenya tanpa diberikan kesempatan untuk bergabung dengan negara Somalia yang saat itu bersatu antara Somalia-Italia dan Somalia-Inggris. Special District Ordinance merupakan kebijakan yang memberikan batasan ruang gerak terhadap wilayah NFD bersama kelompok etnis di dalamnya untuk melakukan mobilisasi. Dengan satu kebijakan yang membatasi ruang gerak dalam satu wilayah mengakibatkan wilayah lainnya tidak mengenali secara baik karakteristik seperti apa yang dimiliki wilayah yang terisolasi tersebut. Dengan warisan Pemerintah Kolonial yang mengisolasi wilayah NFD bersama kelompok Somali di dalamnya, mengakibatkan stereotype 'musuh' karena keinginan kelompok tersebut untuk bergabung bersama 
Somalia dibandingkan berintegrasi dengan Kenya "This long history of conflict tension has created a disorted and hostile image of the Somalis as "enemies" of the Kenyan state" (Otunnu, 1992). Kemudian hal ini didukung oleh konstitusi kemerdekaan Pemerintah Kenya terhadap wilayah NFD yang kurang lebih juga mendukung adanya isolasi dan pembatasan mobilisasi di wilayah tersebut dengan kebijakan Preservation of Public Security Act.

Selain pandangan sebagai 'musuh' sedari Kenya merdeka, faktor lain yang menguatkan pebedaan antara Kenya-Somali dan Kenya lainnya adalah dual-identitas antara pengungsi dari Somalia yang menetap di Kenya sedari tahun 1990-an dan Kenya-Somali. Pengungsi Somalia ini memiliki kemiripan karakter wajah, bahasa dan agama. Jumlah komunitas Kenya-Somali setiap tahunnya semakin membesar setelah kedatangan pengungsi Somalia. Hal ini diakibatkan adanya percampuran antara keduanya, terutama dalam satu wilayah komunitas yang sebelumnya hanya didiami oleh Kenya-Somali yakni Eastleigh, Nairobi. Eastleigh memegang peranan penting dalam perekonomian Kenya karena daerah tersebut merupakan salah satu pusat perekonomian, tidak hanya di Kenya namun juga di Afrika Timur dengan keberagaman barang-barangnya yang mampu dihadirkan oleh para pengusaha Somali. Kontribusi Eastleigh yang sebenarnya menguntungkan perekonomian Kenya menjadi faktor yang dilematis saat kelompok teroris Somalia, Al Shabaab, mulai menjamur di Kenya.

Aktivitas Al Shabaab yang semakin meningkat di Kenya menjadi alasan lain penetrasi atas nilai-nilai permusuhan dalam melihat Kenya-Somali tidak berhasil dilumpuhkan di Kenya. Al Shabaab dipercaya melakukan perekrutan dari kam-kamp pengungsi yang mayoritas dihuni oleh Somalis seperti Kamp Dadaab dan Kamp Kakuma. Kontribusi pengungsi Somalia bersama KenyaSomali di Eastleigh tidak lagi dilihat sebagai upaya menjembatani permusuhan namun lebih kepada sumber dari berbagai kekacauan yang dilakukan oleh Al Shabaab. Pengungsi Somalia dan KenyaSomali segera menjadi sasaran diskriminasi dan represi saat Operasi Keamanan Usalama diberlakukan pada April 2014 (Amnesty International, 2014).

Operasi tersebut secara garis besar memiliki kesamaan dengan operasi keamanan lainnya yang sudah sering dilakukan sejak 
pasca kemerdekaan pada tahun 1963, diikuti pembantaian massal di Garissa November 1980 dan Wajir Februari 1984 (mayoritas Somali), 'penyaringan' etnis Somalis yang tinggal di Kenya pada 1989 dan 1990 (Whittaker, 2015: 642). Etnis Kenya-Somalis sering sekali disalahkan atas berbagai permasalahan keamanan di Kenya yang disebabkan oleh kelompok yang memiliki identitas Somali juga. Aktivitas Al Shabaab sendiri sebenarnya meningkat di Kenya akibat intervensi militer Kenya bernama "Operasi Linda Nchi" sejak Oktober tahun 2011 bersama African Union Mission in Somalia (AMISOM) di Somalia (Horn Affairs, 2014). Pasca intervensi, terhitung teror yang dilakukan Al Shabaab di Kenya per 2014 sudah ada 133 kali (Horn Affairs, 2014).

Penetrasi untuk terus-menerus menganggap Kenya-Somali sebagai musuh pada awalnya memang secara tidak langsung dilakukan Pemerintah Kolonial dalam rangka membendung perluasan wilayah dari kekasiaran Abyssinia dan Italia terhadap wilayah NFD yang harus dilindungi dengan kebijakan Outlying District Ordinance sebagai buffer zone antara kedua koloni tersebut. Perasingan wilayah NFD ini merupakan titik mulanya kemudian Pemerintah Kenya menolak keinginan kelompok Somali untuk bergabung dengan Somalia yang menyebabkan Perang Bandit atau Shifta War setelahnya dengan anggapan bahwa kelompok Somalis merupakan kelompok separatis yang merupakan kumpulan bandit-bandit dan harus diperangi karena mengancam keamanan integrasi nasional Kenya yang baru merdeka. Puncak narasi diskriminasi terhadap keturunan Somali semakin meningkat pasca serangan teror Al Shabaab dekade belakangan ini.

\section{Ancaman terhadap Kebutuhan akan Kebebasan (Freedom Needs)}

Pada freedom needs implementasi yang dapat ditelusuri pada Kenya-Somali dilakukan dengan marginalisasi. Karena pada proses fragmentasi atau pemecahbelahan kelompok tidak terjadi terhadap Kenya-Somali karena yang melakukan pemecahan hanya dari segi wilayah dan dilakukan oleh Pemerintah Kolonial bukan Pemerintah Kenya sebagai topdogs. Juga kuatnya rasa kesatuan sebagai kelompok minoritas yang sulit untuk dipecahbelah.

Di masa kolonisasi, Pemerintah Inggris tidak melakukan 
pembangunan yang terintegrasi antara sosio-ekonomi dan politik wilayah NFD dengan wilayah lainnya di Kenya, hal ini yang mengakibatkan marjinalisasi pembangunan sedari masa kolonisasi hingga Pemerintah Kenya saat ini. "To be precise, no serious attempt was made by the colonial regime to foster the socio-economic and political integration of this area into the rest of the country" (Otunnu, 1992). Menurut laporan Truth, Justice and Reconciliation Commission (2013) yang laporan akhirnya diserahkan kepada Presiden Uhuru Kenyatta, sejak kemerdekaan Kenya, pemerintah telah melakukan marjinalisasi dan tekanan (oppression) dalam sistem terhadap populasi Somali.

Marjinalisasi dan tekanan lainnya yang masuk ke dalam sistem juga dibuktikan berdasar dari hasil laporan berbagai pelanggaran hak asasi manusia yang tidak hanya terjadi pada masa kolonisasi tapi juga pada masa pemerintahan Jomo Kenyatta, Daniel Arap Moi dan Mwai Kibaki. Satuan Polisi dan Militer Kenya di masing-masing pemerintahan telah menjadi pelaku utama dari banyak pelanggaran HAM seperti pembantaian, pembunuhan, penghilangan diri secara paksa, penyiksaan dan perlakuan buruk, pemerkosaan dan kekerasan seksual. Pelanggaran HAM tersebut biasanya terjadi saat operasi keamanan atau negara dalam keadaan status darurat (Kenya Transitional Justice Network, 2013).

Menurut Oucho (2002) dan Oyugi (2000), pengalokasian sumber daya pemerintah pasca kolonisasi mengikuti pola etnisnya. Selama rezim Presiden Kenyatta (1963-1978) etnis Kikiyu mendapat pengalokasian yang cukup, sedangkan pada rezim Presiden Moi (1978-2002) etnis Kalenjin mendapat keuntungan dan perhatian yang cukup besar. Praktik-praktik tersebut menyebabkan ketidakseimbangan pembangunan di berbagai wilayah lainnya, termasuk NEP dengan etnis Somali (Alwi \& Schech, 2004). Pendistribusian kekuasaan tidak merata dan mengikuti kepentingan dari kelompok mayoritas adalah bagian dari indikasi kekerasan struktural sedang terjadi. Alokasi sumber daya berdasar pada etnisitas sangat memenangkan kepentingan satu pihak dan mengurangi kepentingan pihak lainnya. Dan hal tersebut terjadi saat kelompok mayoritas menjabat sebagai presiden. 


\section{Kesimpulan}

Dengan menggunakan pendekatan kekerasan struktural (structural violence) dari Johan Galtung dapat disimpulkan bahwa terdapat pelemahan kebutuhan dasar yang terjadi terhadap kelompok minoritas etnis Kenya-Somali melalui ancaman kelangsungan hidup, kesejahteraan, identitas dan kebebasan. Masing-masing dari kebutuhan tersebut dapat dilalaikan dengan distribusi kebutuhan dasar yang tidak merata oleh pemegang kekuasaan. Begitu pula dengan narasi kecurigaan bahwa etnis Kenya-Somali 'tidak bersahabat' yang ditimbulkan akibat pemegang kekuasaan yang dipengaruhi oleh konstruksi inferioritas pada masa kolonial dan mengakibatkan peniruan terhadap perilaku pemerintah kolonial dengan pengadopsian kebijakan-kebijakan yang diskriminatif terhadap etnis Kenya-Somali pasca kolonisasi. Superioritas dan inferioritas atas masing-masing identitas etnis mengakibatkan kesenjangan sistem yang bergantung pada siapa kelompok yang sedang berkuasa.

Bentuk ancaman terhadap Kenya-Somali dalam kelangsungan kebutuhan akan keamanan masih pada kesulitan dalam mendapatkan kartu identitas sebagai tanda warga negara Kenya. Hal ini menjadikan Kenya-Somali sasaran untuk mendapat kekerasan dari angkatan bersenjata Kenya saat terjadi operasi keamanan yang diarahkan kepada imigran Somalia. Dari kebutuhan kesejahteraan, kemiskinan absolut masih terjadi di North Eastern Province, begitu pula infrastruktur fisik dalam pembangunan sumber mata air dan sanitasi, juga akses terhadap pendidikan dan kesehatan. Secara psikis, ancaman terhadap identitasnya sebagai etnis Somali masih dirasakan karena yang dilakukan adalah narasi bahwa kelompoknya berbahaya dan menimbulkan xenophobia di kalangan masyarakat Kenya. Begitu pula dalam kebutuhan akan kebebasan dimana untuk dapat melakukan perpindahan menggunakan transportasi saja terdapat perlakuan yang berbeda antara etnis Kenya-Somali dan masyarakat Kenya lainnya karena pemeriksaan keamanan yang berlebihan. 


\section{Referensi}

Alwi, A. \& Schech, S. 2004. "Ethnic Inequalities in Education in Kenya", International Education Journal, Volume 5, pp. 266-274.

Amir, J. 2014. Kenya's Wagalla massacre 30 years later. [WWW] Al Jazeera. Tersedia di: http://www.aljazeera.com/indepth/ features/2014/02/kenya-wagalla-massacre-30-yearslater-201422682831165619.html [diakses 1 Juli 2016].

Amnesty International. 2014. Kenya: Somalis scapegoated in counterterror crackdown. [WWW] Amnesty International. Tersedia di: https://www.amnesty.org/en/latest/news/2014/05/kenyasomalis-scapegoated-counter-terror-crackdown/ [diakses 7 Juni 2016].

Fanon, F., 1963. The Wretched of the Earth. New York: Grove Press.

Fanon, F., 1986. Black Skin, White Mask. London: Pluto Press.

Galtung, J. 1969. "Violence, Peace, and Peace Research", Journal of Peace Research, Volume 6 pp 167-191.

Galtung, J. 1978. The Basic Needs Approach.

Galtung, J. 1990. "Cultural Violence", Journal of Peace Research, Volume 27, p. 292.

Hassan, A. I. 2012. Legal Impediments to Development in Northern Kenya. [WWW] Muslim Conditions. Tersedia di: http://english. muslimconditions.com/ahmed-issac-legal-impediments-todevelopment-in-northern-kenya.html [diakses 23 Oktober].

Horn Affairs. 2014. Kenya faced 133 terror attacks since Somalia intervention. [WWW] Horn Affairs. Tersedia di: http:// hornaffairs.com/en/2014/09/03/kenya-faced-133-terrorattacks-since-somalia-intervention/ [diakses 7 Juni 2016].

Human Rights Watch. 2015. Kenya Counterterrorism Operations Undermine Rights. [WWW] Human Righst Watch. Tersedia di: $\quad$ https://www.hrw.org/news/2015/01/29/kenyacounterterrorism-operations-undermine-rights [diakses 1 Juli 2016].

International Crisis Group. 2012. “The Kenyan Military Intervention in Somalia - African" Report No.184, 15 Febuari, pp 1-24.

IRIN. 2015. Map: Al Shabaab incidents in Kenya 2008-2014. [WWW] IRIN. Tersedia di: http://newirin.irinnews. 
org/dataviz/2015/4/2/map-al-shabaab-incidents-inkenya-1997-2014 [diakses 29 Oktober 2015].

Kenya Human Rights Commission. 2015. Foreigners at Home: The Dilemma of Citizenship in Northern Kenya. Nairobi: Kenya Human Rights Commission.

Kenya National Bureau of Statistics. 2010. The 2009 Kenya Population and Housing Census: "Counting Our People for the Implementation of Vision 2030". Population Distribution by Political Units, Volume 1B.

Kenya National Commission on Human Rights. 2007. An Identity Crisis? A Study on the Issuance of National Identity Cards in Kenya. Nairobi: Kenya National Commission on Human Rights.

Kenya National Commission on Human Rights. 2007. An Identity Crisis? A Study on the Issuance of National Identity Cards in Kenya. Nairobi: Kenya National Commission on Human Rights.

Kenya National Bureau of Statistics. 2015. Economic Survey, Nairobi: Kenya National Bureau of Statistics

Kenya Transitional Justice Network. 2013. The Truth Justice and Reconciliation Commission Summary, Nairobi: Kenya Transitional Justice Network.

Low, D. A. \& Smith, A. 1976. History of East Africa. Volume 3. Oxford: Clarendon Press.

Michalpoulos, S. 2012. VOX CEPR's Policy Portal. [WWW] Voxeu. Tersedia di: http://www.voxeu.org/article/long-run-effectsscramble-africa [diakses 12 Maret 2016].

Mwaura, N., 2005. Kenya Today: Breaking the Yoke of Colonialism in Africa. New York: Algora Publishing.

Otunnu, O. 1992. "Factors Affecting the Weatment of KenyanSomalis and Somali Refugees in Kenya: A Historical Overview", Refuge, Volume 12, pp. 21-26.

Oyugi, W. O. 2000. "Politicised Ethnic Conflict in Kenya A Periodic Phenomenon". p. 4.

Patinkin, J. 2014. Somalis in Kenya face mistrust. [WWW] Tersedia di: http://www.csmonitor.com/World/Africa/2014/0617/ Somalis-in-Kenya-face-mistrust [diakses 13 Juni 2016].

Pink, W. T. \& Noblit, G. W. 2007. International Handbook of Urban 
Education. In: Springer Science \& Business Media. Michigan: University of Michigan.

Ringquist, M. J. 2011. “Bandit or Patriot: The Kenyan Shifta War 1963-1968", Baltic Security and Defence Review, 13(1), pp. 100121.

Robins, S. 2011. “To Live as Other Kenyans Do: A Study of the Reparative Demands of Kenyan VIctims of Human Rights Violation". International Center for Transitional Justice.

Save the Children. 2007. Vulnerability and Dependency in Four Livelihood Zones in North Eastern Province, Kenya. Assessed Using the Household Economy Approach (HEA), Fairfield: Save The Children Federation, Inc.

Tripodi, P. 1999. The Colonial Legacy in Somalia: Rome and Mogadishu from Colonial Administration to Operation Restore Hope. London: Macmillan Press.

Whittaker, H. 2015. "Legacies of Empire: State Violence and Collective Punishment in Kenya's North Eastern Province, c. 1963-Present", The Journal of Imperial and Commonwealth History, 43(4), pp. 641-657.

Whittaker, H. A. 2012. “The Socioeconomic Dynamics of the Shifta Conflict in Kenya, c.1963-8", Journal of African History, Volume 53, pp. 391-408.

Yabarag, M. 2015. Garissa Massacre 2015 vs Wagalla Massacre Wajir 1984. [WWW] Wardheer News. Tersedia di: http:// www.wardheernews.com/garissa-massacre-2015-vs-wagallamassacre-wajir-1984/ [diakses 1 Juli 2016]. 